\title{
Die kerkregtelike toepassing van die reëls van 'natuurlike geregtigheid' op grond van die Skrif $^{3}$
}

\author{
C.J. Smit \\ Gereformeerde Kerk Noordbrug \\ POTCHEFSTROOM
}

\begin{abstract}
The exploration of the rules of natural justice in church polity on the principles given in Scripture
\end{abstract}

Church polity is not the exercising of justice apart from justice in general, but merely the application of justice in another sphere using other procedures. Therefore the principles of fundamental justice, which underlie by far most legal systems, also apply to church polity. The principles of fundamental justice, which are unfolded in the rules of natural justice, are also found in Scripture. These principles include the following aspects: the right to be heard; the meeting of legitimate expectations; the provision of the reasons for the judgements; and the fact that no one may judge his own case.

The principles of fundamental justice are also found in Scripture and can therefore be regarded as Scriptural principles to ensure procedural fairness. In this article these principles are seen as the fundamental basis for church judicature.

\section{Oriëntering}

\subsection{Noodsaaklikheid}

Regspraak oor kerklike sake, soos gereël in artikels 31 en 71 tot 80 van die Kerkorde van die Gereformeerde Kerke in Suid-Afrika, is een van die

3 Oorspronklik as referaat gelewer voor die Kerkhistoriese en Kerkreg Werkgemeenskap van Suidelike Afrika op 18 Januarie 1994. 
essensiële funksies van kerklike vergaderings. Hoewel baie navorsing gedoen is oor die kerkregtelike beginsels van en prosedures vir kerklike appèlle en tugsake kon ek geen bydrae opspoor oor die kerkregtelike toepassing van die reëls vir 'natuurlike geregtigheid' - soos dit in die Administratiefreg verwoord word - vir kerklike regspraak op grond van die Skrif nie.

Uit die algemene reg blyk die besonder belangrike plek van die toepassing van die reëls van 'natuurlike geregtigheid' pertinent in die geregtelike hersiening van administratiewe handelinge, ook regshandelinge van ander instansies as geregshowe - waaronder kerklike regspraak. Die hersieningshof se taak is om hom in elke geval te vergewis of die beginsels van fundamentele geregtigheid toegepas is, veral ook aan die hand van die genoemde reëls (Wiechers, 1984:237; Baxter, 1984:575; Rose Innes, 1963:9, 14, 15).

Omdat die reëls van 'natuurlike geregtigheid' dus buitendien in kerklike regspraak toegepas moet word om by te dra tot die daarstelling van 'n algemene legaliteitsbasis (vgl. Wiechers, 1984:237), is 'n ondersoek na die kerkregtelike toepassing van genoemde reëls op grond van die Skrif uiteraard noodsaaklik. Ek verwys hier na die regsreëls wat in die Administratiefreg hoofsaaklik onder die audi alteram partem- en die nemo iudex in propria causa-beginsel saamgegroepeer word (Wiechers, 1984:236; Sadler, 1979:185).

\subsection{Beperking}

Die doel met hierdie bydrae is nie om kerklike regspraak soos die Strafprosesreg van die howe, of die Burgerlike Prosesreg te laat funksioneer nie. Die proseswette vir hierdie handelinge het na aanleiding van die spesifieke behoefte van die howe uitgekristalliseer (Strafproseswet; Wet op die Hooggeregshof; Wet op Landdroshowe). Naas die reëls wat egter in genoemde wette vervat is, is daar ook ander reëls waarin universele geregtigheidsbeginsels weerspieël word en wat 'n fundamentele funksie in alle vorms van regspraak vervul (Baxter, 1984:536-538). Hierdie reëls, wat in algemene regsterme verwoord word as die reëls van 'natuurlike geregtigheid' (Baxter, 1984:536), se belangrikheid vir kerklike regspraak word in hierdie bydrae nagegaan. 
In hierdie bydrae word ook nie ingegaan op die regsfilosofie van die reëls van 'natuurlike geregtigheid' en op die Skriftuurlike houdbaarheid van die term al dan nie. Die beperking van hierdie ondersoek trek saam in die vraag of die belangrikheid van die reëls van 'natuurlike geregtigheid' vir kerklike regspraak slegs vanweë die juridiese eis bepaal word, en of daar ook Skrifgegewens is op grond waarvan hierdie reëls toegepas moet word.

\subsection{Uitgangspunt}

Die uitgangspunt vir' $n$ ondersoek na die Skriftuurlike belang van die reëls van 'natuurlike geregtigheid' vir kerklike regspraak lê vir 'n gelowige navorser in die voorveronderstelling dat die oorsprong van die reg in God setel. Dit hou in dat die wese, die inhoud en die geldigheid van die reg deur God bepaal word - of Hy daarin erken word of nie (Baur, 1965:5 e.v.; Bohatec, 1961:569-571; Rutgers, 1894:34, 35).

Hierdie uitgangspunt veronderstel nie dat God se Woord 'n paradigma bied van waaruit die belang van die reëls van 'natuurlike geregtigheid' vir kerklike regspraak verken kan word nie. Die ondersoek gaan juis daaroor of God nie beginsels, selfs aanduidinge van fundamentele geregtigheid, in sy Woord bied waarvolgens die toepassing van die reëls vir 'natuurlike geregtigheid' vir kerklike regspraak as 'n Skrifopdrag verstaan moet word nie.

\subsection{Die reg voor die sondeval}

Aanvanklik, na die skepping, was daar geen uiterlike regsorde nodig nie. $\mathrm{Nie}$ dat daar toe geen (ingeskape) wet was nie - wel dat die formele wet en alle uiterlike regsreëls vir die ordening van die samelewing toe nie nodig was nie. Die regsorde wat toe geheers het, was 'n innerlike regsorde wat in die volkome harmonie tussen Skepper en skepsel bestaan het. Hiervan is die eerste huwelik, voor die sondeval, 'n sprekende voorbeeld. Daar was geen uiterlike wet nodig om die orde in en die instandhouding van die huwelik te bepaal nie. Aan daardie regsorde moet gedink word as God se ongeskrewe reg op die totaliteit van die mens en die mens se onbelemmerde erkenning van God se reg deur sy volkome ooreenstemming met God se wil (Fabius, 1895:15, 16). 


\subsection{Die behoud van fundamentele reg na die sondeval}

$\mathrm{Na}$ die sondeval (Gen. 3 ) is die mens se kennis van die reg verduister. Sy regsbesef het hy egter nie kwytgeraak nie. Voortaan sou die mens 'n besef hê, alhoewel dikwels vaag, van wat reg is, maar 'n vanselfsprekende kennis van die reg sou hom steeds ontwyk. Vanweë die mens se algemene regsbesef sou hy tóg in staat wees om reg te positiveer, of hy God erken of nie (Rom. 2:14, 15; Inst. I. 4. 4., vgl. Calvyn, 1984; Bouwman, 1970a:8; Fabius, 1890:6, 7).

As gevolg van die ingeskape oorsprong van die reg kan gepraat word van fundamentele geregtigheid, wat op universele regsbeginsels berus. Hierdie regsbeginsels, wat deur gelowiges óf ongelowiges in regsreëls gepositiveer kan word, vorm die raamwerk waarbinne regspraak moet plaasvind, ongeag die regsteorie waarop die regspraak ook al mag rus (Stoker, $1967: 113,114 ; 1970: 9,10)$. Op die verskeie teorieë oor die oorsprong van die reg word hier nie ingegaan nie.

\subsection{Die fundamentele reg met betrekking tot kerklike regspraak}

In die algemene reg kom die beginsels van fundamentele geregtigheid tot uiting in die afdwingbare handhawing van orde en die harmoniëring van belange. In onderskeid met die algemene reg is die aard van kerklike regspraak geestelik. Dieselfde beginsels wat geld vir fundamentele geregtigheid kom in kerklike regspraak geestelik tot uiting deur die handhawing van die eer van God en deur versoening in die kerk te bewerkstellig (Kerkorde, art. 71; Smit, 1985:304). Hierdie eiesoortigheid van kerklike regspraak, wat saamtrek in die handhawing van Christus se Koningsreg deur die navolging van sy Woord, maak van die kerklike reg 'n ius sui generis (Sadler, 1979:5), wat uit die oogpunt van die algemene reg as 'n interne verbandsreg omskryf word (Pienaar, 1982:271 e.v.). Vir die daarstelling van 'n algemene legaliteitsbasis vir kerklike regspraak en derhalwe vir die handhawing van fundamentele geregtigheid binne die interne verbandsreg van die kerk, is die toepassing van die reëls van 'natuurlike geregtigheid' noodsaaklik (Baxter, 1984:575).

Vir die geestelike aard van kerklike regspraak is dit by uitstek van belang dat die toepassing van die reëls van 'natuurlike geregtigheid' deur die 
liefdesgebod (Matt. 22:37-40) gedra word. Ook in hierdie konteks vind die liefdesgebod beslag in die oproep om aan ander te doen soos jy sou wou hê dat aan jouself gedoen moet word, oftewel dat jy nie aan ander moet doen wat jy nie aan jouself gedoen sou wou hê nie (Matt. 7:12).

\subsection{Nie 'n rigiede paradigma nie}

Hierdie bydrae streef nie 'n rigiede paradigma na vir die wyse waarop die reëls van 'natuurlike geregtigheid' toegepas behoort te word nie. Uit die algemene reg word die uitgangspunt van Baxter (1984:541) hier gehandhaaf:

If the principles are to serve efficiently the purposes for which they exist, it would be counterproductive to attempt to prescribe rigidly the form which the principles should take in all cases.

Baxter staaf sy uitgangspunt met die uitspraak van L.J. Tucker in Russell versus Duke of Norfolk:

The requirements of natural judgement must depend on the circumstances of the case, the nature of the inquiry, the rules under which the tribunal is acting, the subject matter which is being dealt with, and so forth.

\section{Die audi alteram partem-beginsel}

Hierdie beginsel wat in die algemene reg geformuleer is, beteken letterlik: 'Hoor die ander kant (saak)'. Om ook die ander kant van die saak aan te hoor en daarmee in 'n billike verhoor reg te laat geskied aan albei kante, moet dié beginsel in sy differensiëring in ag geneem word (vgl. Baxter, 1984:544-557; Wiechers, 1984:237-243; Corder, 1980:156), wat vir die doel van hierdie bydrae soos volg uiteengesit word:

* Die reg van die betrokkene(s) om aangehoor te word.

* Die voldoening aan geregverdigde verwagtinge.

* Die verskaffing van die redes vir die uitspraak.

\subsection{Die reg om aangehoor te word}

Uit gevestigde gebruik in die Skrif blyk dat dit as 'n Skrifbeginsel beskou moet word dat niemand ongehoord veroordeel mag word nie (vgl. onder meer Eks. 18:13-16; 1 Kon. 7:7). Hierdie beginsel is ook in die Fariseërs 
se wette opgeneem en was in die tyd van Jesus op aarde welbekend; daarom sê Nikodemus by geleentheid toe aangedring is op Jesus se uitlewering: "Volgens ons wet kan ons mos nie sommer iemand veroordeel sonder om eers sy kant van die saak te hoor en vas te stel wat hy doen nie" (Joh. 7:51).

In Matteus 5:23, 24 en in 18:15 word die beginsel gestel dat kwaad en onreg tussen mense slegs uit die weg geruim kan word deur gehoor te word. Soos die betekenis van die woord verhoor dit reeds uitspel, behoort die hele prosedure van 'n verhoor daarop ingestel te wees om albei kante aan te hoor (Bouwman, 1970b:622; Baxter, 1984:545, 546; Wiechers, 1984:237-239; Corder, 1980:161, 162).

Dit is duidelik dat hierdie Skrifbeginsel wat ook in die algemene reg reflekteer waar die hoofregter, verwysend na die boek Genesis, in die uitspraak in $R$. versus Chancellor, Masters and Scholars of the University of Cambridge (1723), konstateer: “... even God himself did not pass sentence upon Adam before he was called upon to make his defence ..." (Taitz, 1982:254).

Hierdie beginsel geld vanselfsprekend ook vir kerklike appelsake. Voordat 'n meerdere vergadering oor 'n appèl besluit, moet aan albei kante volle geleentheid gegee word om aangehoor te word. Die reg om aangehoor te word, veronderstel 'n aantal regsreëls met betrekking tot kerklike regspraak wat hier soos volg gegroepeer en uiteengesit word:

\subsubsection{Die kennisgewing van 'n beoogde verhoor}

Skriftuurlik gesien, kom die beginsels van die reg nooit in spanning met die liefde nie. God openbaar sy liefdestrou as 'n supplement van sy reg en geregtigheid (Jer. 9:24; Smit, 1985: 159, 160). Sy liefde kom juis deur sy reg tot openbaring - in die veroordeling van sy enigste Seun ter wille van ons sondes (1 Joh. 4:9). Vir die mens geld die Skrifwaarheid dat reg juis deur liefde tot stand kom (Rom. 13:10; vgl. Murray, 1979:164).

God se liefde, soos vergestalt in die eis tot naasteliefde (Matt. 22:37-40), eis ' $n$ regverdige verhoor wat in die eerste plek 'n ordelike kennisgewing van die verhoor of appèlsaak veronderstel.

Die Skrifopenbaring van God wys reeds in die Mosaiese tyd op die 
veronderstelling van die reël van kennisgewing: "Toe Moses die volgende dag gaan sit om hofsake te verhoor, het daar van die oggend af tot die aand toe mense vir hom gestaan en wag" (Eks. 18:13.) Die betrokkenes het dus alreeds op Moses gewag. Die volk is behoorlik in kennis gestel van die tyd en plek van die hofsake.

Uit die voorafgaande kan afgelei word dat die reg om aangehoor te word by die kennisgewing van die betrokke vergadering begin. Sonder hierdie kennisgewing is dit nie moontlik vir die betrokkene(s) om betyds voor te berei en om te verskyn, of om 'n geskrewe uiteensetting voor te hou nie, en is ' $n$ regverdige verhoor derhalwe nie moontlik nie.

Baxter (1984:544, 545) toon aan dat die reël van behoorlike kennisgewing so belangrik in die algemene reg beskou word dat hofsake telkemale tersyde gestel is waar nie aan die reël voldoen is nie en 'n regverdige verhoor gevolglik gekortwiek sou word. Trouens, die hof het in sekere gevalle uitdruklik beslis dat 'n bepaalde vergadering waarvan , nie behoorlik kennis gegee is nie, ongeldig is (Sadler, 1979:85).

In die geval van 'n klag behels die kennisgewing van die verhoor ook die substansie van die klag, asook die omstandighede waarin die klag gesitueer is. Volgens die liefdeseis van die Skrif is dit essensieel dat die aangeklaagde duidelikheid moet hê oor die inhoud van die klag, soos dit ook deur die reëls van 'natuurlike geregtigheid' vereis word, anders word hy in sy verdediging benadeel (Corder, 1980:160; Visser, 1989:516, 517).

\subsubsection{Die reg vir voorbereiding}

'n Deeglike ondersoek verg behoorlike tyd vir voorbereiding. Om grondige vrae, waartoe die regters reeds in die Ou-Testamentiese tyd gelas is (Deut. $13: 14 ; 17: 4 ; 19: 18)$ te beantwoord, moet daar binne die perke van billikheid voldoende tyd vir voorbereiding gegee word. In die Woord van God het die soeke na reg die betekenis om voor God te verskyn (Eks. 21:6; 22:8; Deut. 19:17), want Hyself is die verskaffer van reg (Deut. 1:17).

'Om voor God te verskyn', dit wil sê om in die heiligdom van die plek van aanbidding te kom, waar ook die regspraak gelewer word, is om God se reg in jou lewe te erken, want hier spreek God en Hy alleen. Om deur onvoldoende voorbereiding die regters wat deur God daargestel is die geleentheid te ontneem om in waarheid te sê 'So sê die Here', is 'n vergryp 
teen die heiligheid van God self (vgl. Craigie, 1981:270). Om voor God te verskyn beteken derhalwe in hierdie konteks grondige selfondersoek en behoorlike ondersoek na alle moontlike aspekte rondom die vermeende regskrenkende besluit. Dit is ondenkbaar dat regverdige regspraak volgens die relevante Skrifgegewens uitgeoefen kan word indien belanghebbendes nie binne billike perke genoegsame voorbereidingstyd ontvang nie.

\subsubsection{Toegang tot die relevante skriftelike stukke}

Die kerklike vergadering teen wie se besluit appèl aangeteken word, kom voor die Skrifopdrag te staan om aan ander te doen wat jy aan jouself gedoen wil hê (Matt. 7:12; HK. Son. 42, vr. 111), hier binne die konteks van regsbevordering: om die leuen teë te gaan en die waarheid te dien. Daarom moet so 'n vergadering die besluite en alle relevante skriftelike stukke, binne redelike perke, tot die beswaarde se beskikking stel, sodat hy sy saak behoorlik teen moontlike regsbenadelende besluite en oorwegings kan voorberei (Visser, 1989:517). Indien 'n kerklike vergadering dit egter as verantwoordelik beoordeel om nie die aangevraagde inligting in dieselfde vorm waarin die vergadering dit te wete gekom het aan die belanghebbende beskikbaar te stel nie, kan dit nie as 'n aantasting van die onderhawige regsreël beskou word nie. Voldoende relevante gegewens moet egter aan die belanghebbende gebied word, sodat hy sy saak onbelemmerd kan stel (Wiechers, 1984:239).

In die algemene reg word die bepaalde reël selfs as van deurslaggewende belang vir ' $n$ regverdige verhoor beskou. Indien die belanghebbende toegang geweier word tot die besluite wat hom in die verdediging of motivering van sy saak raak, word 'n regverdige verhoor hom inderwaarheid geweier (vgl. Taitz, 1982:272, 273; Corder, 1980:164167; Wiechers, 1984:239, 240; Baxter, 1984:546-551).

\subsubsection{Die reg om kerkregtelike advies in te win}

Uit die Skrifopdrag vir behoorlike ondersoek (kyk 2.1.2) ontstaan ook die reg om vooraf kerkregtelike advies in te win, sowel oor die prosedure as oor die inhoudelike aspekte van die saak. Veral waar dit oor ingewikkelde kerkregtelike aangeleenthede gaan, mag die reg van kerkregtelike advies deur 'n kundige niemand weerhou word nie. 
Die reg tot kerkregtelike advies beteken volgens die gereformeerde kerkreg nie noodwendig regsverteenwoordiging nie, maar toegang tot kundigheid om in staat gestel te word om 'n saak op die korrekte en beste wyse voor te hou. Dit beteken egter nie dat daar nie ook van 'n verteenwoordiger gebruik gemaak kan word wanneer dit nodig is nie (De Jong, 1918:112; Bouwman, 1970b:622). Kerkregtelike advies behoort in die eerste plek daartoe by te dra om die betrokkene persoonlik in sy gewete voor God te stel. Dit gaan immers om die reg deur die waarheid te handhaaf. Weerhouding van kerkregtelike advies kan verhinder dat die betrokkene die geleentheid gebied word om op die beste wyse aangehoor te kan word.

\subsubsection{Die reg om mondeling te getuig}

Die Skriftuurlike beginsel om behoorlik aangehoor te word (kyk 2.1), bied vir die betrokkenes die reg om persoonlik te getuig. Die audi alteram partem-beginsel ly egter, na gelang van omstandighede, nie noodwendig daaronder indien nie van hierdie reg gebruik gemaak word nie (Baxter, 1984:552; Wiechers, 1984:238; Corder, 1980:163). Die betrokkene mag met 'n behoorlik skriftelike uiteensetting volstaan.

Indien dit om geldige redes nodig is - 'n geval waaroor die vergadering besluit - mag ' $n$ betrokkene van die ou kerklike metode van 'n 'mond' (plaasvervanger) gebruik maak. Die doel van 'n 'mond' is nie om soos 'n advokaat in 'n hof die beste uitspraak vir sy kliënt te beding nie. Die doel van 'n 'mond', wanneer die betrokkene om 'n geldige rede nie self sy saak kan stel nie, is dat die saak bloot saaklik voorgehou word, sodat die vergadering behoorlik daarvan kan kennis neem. Eintlik behoort 'n betrokkene self sy saak te stel. Dit gaan immers om die gelowige se persoonlike verantwoordelikheid voor God waarvan hy of sy rekenskap gee (De Jong, 1918:112; Bouwman, 1970b:622; Spoelstra, 1989:400, 401).

\subsubsection{Die reg op getuienis en op kruisverhoor}

Die negende gebod gaan uit van die reg om getuienis af te lê en derhalwe ook getuies op te roep (HK. Son. 43). Hierdie reg is ook in die Skrif as 'n waardevolle en merendeels noodsaaklike metode vasgelê om in die ondersoekfase van die verhoor die feite vas te stel en so by die waarheid te kom (Deut. 17:6; 19:15; Num. 35:30; Matt. 18:16; Joh. 8:17; 2 Kor. 
13:1; 1 Tim. 5:19; vgl. Craigie, 1981:250, 251, 269, 270; Grosheide, 1954:282, 283; Ridderbos, 1967:142,1 43).

Eweneens word die reg van toetsing van getuienis, soos dit in die algemene reg in kruisverhoor tot uiting kom, in die Skrif gestel (Spr. 18:17). Die werkwoord wat in hierdie verband in die Ou Testament gebruik word, chakar (1 Sam. 20:12; Job 13:9; Ps. 139:1,23; Spr. 23:30; 25:2; 28:11), het die betekenis van 'deursoek', 'deurvors', 'ontgin', 'eksamineer' (Koehler \& Baumgartner, 1958:328). Waar iemand in Spreuke 18:17 in 'n regsaak 'ondervra' (1983-Bybelvertaling), of 'terdeë ondersoek' (1933/53-Bybelvertaling) word, het dit die onmiskenbare betekenis van toetsing van getuienis, soos dit in die algemene reg in kruisverhoor tot uiting kom (Gispen, 1954:59, 60).

Die gewone kerklike prosedure by 'n tugsaak of 'n appèlsaak is dat die kerklike vergadering eers die saak aanhoor en dit dan na 'n kommissie verwys om hom te adviseer (Spoelstra, 1986:110-113). In 'n tugsaak behoort die reg om getuienis in te win en kruisverhoor uit te voer voor die hele kerkraad uitgeoefen te word (Spoelstra, 1989:400). Op 'n meerdere vergadering word hierdie reg vanweë praktiese redes merendeels voor die kommissie uitgeoefen. Omdat dit die verantwoordelikheid van die kerkvergadering is wat die ondersoek waarneem om die waarheid vas te stel, het die vergadering ook die reg om getuienis te verkry (Sadler, 1979:128, 129).

\subsubsection{Die reg tot appèl}

In die kerk is daar slegs een heerskappy, dié van Jesus Christus. In die uitvoering van sy heerskappy maak Hy ook van diensknegte gebruik wat Hy vir die doel geroep het. Hierdie diensknegte is egter sondige mense wat in hulle regspraak eensydig kan oordeel; daarom is die Skrifbeginsel van meer kerke se besluite oor sake vir ons in Handelinge 15 gegee (Calvyn, 1970:116; Du Plooy, 1982:228, 240; Bouwman, 1970b:47 e.v.). In hierdie Skrifgedeelte word die beginsel aangedui vir sowel die bestaan van meerdere vergaderinge as die reg tot appèl, soos dit verwoord word in die Kerkorde van die Gereformeerde Kerke in Suid-Afrika, artikel 30 en 31. Besluite van kerklike vergaderinge kan en moet trouens in die geval van vermeende regskrenking vir beoordeling aan meer kerke (die naaste meerdere vergadering) voorgelê word. 


\subsubsection{Die reg tot verdediging}

In kerklike regspraak, vanweë 'n appèl, gaan dit om 'n beswaar teen 'n besluit van die kerkraad of ' $n$ meerdere vergadering. Tot dusver is hier oor die regte van die beswaarde onder die audi alteram partem-beginsel gehandel. Op dieselfde Skrifgronde geld hierdie beginsel egter ook vir die regte van die betrokke vergadering wat die besluit geneem het.

Anders as die kerkraad, kan die belanghebbende meerdere vergaderings nie persone aanwys wat in die geval van 'n appèl die verweer 'namens' hulle moet behartig nie. Kragtens die ad hoc-beginsel waarop meerdere vergaderings volgens die gereformeerde kerkreg saamgestel word en funksioneer (Bouwman, 1970b:17, 22; Du Plooy, 1982:240 e.v.), kan 'n 'verweer' nie aangebied word namens 'n vergadering wat nie meer bestaan, en wat in elk geval ook geen regspersoon kan wees nie.

'n Mindere vergadering benoem deputate wat in geval van 'n appèl teen sy besluit bloot as toeligters van die besluit by die meerdere vergadering optree. Die toeligting bestaan daaruit dat die motivering vir die besluit voorgehou word. Nuwe gegewens behoort dus nie aangebied te word nie. Die gronde van die appèl behoort ook nie deur die toeligters beredeneer te word nie. Beoordeling van die appèlgronde is die taak van die meerdere vergadering wat oor die appèl moet besluit. Omdat die toeligters, ongeag die inhoud van die appèl, bloot die agtergrond en die motivering van die besluit behoort weer te gee, is dit nie nodig dat hulle vooraf insae in die appèl kry nie (Spoelstra, 1986:108).

Hierdie prosedure stel die vergadering in die geleentheid om albei kante behoorlik aan te hoor: enersyds die redes vir en die gronde van die appèl en andersyds die agtergrond en die motivering van die besluit wat geneem is.

Die repliek van die toeligters, nadat albei kante van die saak aangehoor is, het eintlik ten doel om die agtergrond en die motivering van die besluit, wat in die verhoor nie voldoende aandag ontvang het of nie in die regte konteks gestel is nie, in ooreenstemming met die waarheid te herbeklemtoon. 


\subsection{Voldoening aan geregverdigde verwagtinge}

Die reël van geregverdigde verwagtinge ("legitimate expectations") is ' $n$ nuwe formulering wat die eerste keer gebruik is in die Engelse reg in 'n hofuitspraak in 1969 (Corbett et al., 1989(4):754). Sedertdien is hierdie reël meer kere toegepas, gewoonlik met betrekking tot prosedure. Daar is onsekerheid of hierdie reël ook substantief op die inhoud van 'n saak toegepas kan word (Craig, 1992:92).

Craig (1992:81, 87) siteer J. Dawson in Attorney-General for New South Wales versus Quin:

It is the legitimate expectation of the continuation of the benefit or advantage in ... which may make it unfair to deprive a person of a benefit or advantage which he has enjoyed without an adequate hearing. It is the assurance of a hearing - not the expectation of the ultimate benefit or advantage - which may make it unfair to withdraw the benefit or privilege in ... without a hearing.

... there was a legitimate expectation, engendered by a promise made to follow a particular procedure, that the promise would be fulfilled. It is sufficient to say that, the promise to follow a certain procedure having been made, it was fair that the public authority should be held to it.

Ook in die Suid-Afrikaanse reg is omstandighede gevind waar regsbenadeling nie slegs volgens die gangbare maatstawwe van benadeling van vryheid, benadeling van eiendom, of benadeling van gevestigde regte plaasvind nie, maar ook op grond van die onvoldoening aan geregverdigde verwagtinge (Corbett et al., 1989(4):761 e.v.).

Die Skriftuurlike fundering van die reël van voldoening aan geregverdigde verwagtinge lê daarin dat God onveranderlik is in sy wese (1 Sam. 15:29) en daarom ook in sy besluite (Heb. 6:17). Die regsbeginsels wat Hy aan die mens in sy Woord bekend maak, moet in alle vorms van regshandhawing gehandhaaf word. Die reël van geregverdigde verwagtinge is op die Skrifeis van 'n regverdige verhoor gegrond.

'n Beswaar kan byvoorbeeld 'n geregverdigde verwagting ten opsigte van die volgende aspekte hê:

* Om toegang te kry tot die genotuleerde besluit waarteen hy beswaard is.

* Om van kerkregtelike advies gebruik te mag maak. 
* Om van 'n plaasvervanger gebruik te mag maak indien sy gesondheid dit vir hom bemoeilik om sy eie saak behoorlik te stel.

* Sonder dat die presidentereg in die gereformeerde kerkreg geld, is dit ook 'n geregverdigde verwagting dat 'n saak wat persone raak in camera aangehoor word waar dit byvoorbeeld 'n ongeskrewe maar jarelange gebruik by verhoorvergaderings is.

Uit die voorafgaande blyk dat geregverdigde verwagtinge gewoonlik ontstaan op grond van die reëls van fundamentele geregtigheid. Die verhoorvergadering behoort die beswaarde met betrekking tot hierdie verwagtinge volgens die onderhawige regsreël gelyk te gee.

\subsection{Verskaffing van die redes vir die uitspraak}

Die belangrikheid daarvan dat 'n kerklike vergadering die redes vir sy uitspraak moet gee, is omdat die gesag nie in die vergadering setel nie, maar in die Woord van God. Christus het nie sy gesag aan mense of aan ' $n$ instansie oorgedra nie, maar Hy oefen self sy gesag uit deur sy dienaars wat getrou na sy Woord luister (Spoelstra, 1992:917; Smit, 1984:81-83). Omdat dit as't ware Christus is wat die uitspraak deur sy geroepe dienaars gee, moet die redes vir die uitspraak op die Woord gegrond wees (2 Kor. $4: 2$; 1 Pet. 5:3; Luk. 22:25, 26; 2 Kor. 3:5, 6; 2 Tim. 2:15). 'n Kerkraad kan byvoorbeeld nie ' $n$ persoon onder tug plaas sonder om redes vir die handeling te verstrek nie. Dit sou op tirannie neerkom.

Die redes vir die uitspraak moet bekend gemaak word, sodat die een wat verkeerd was, veral in die geval van 'n tugsaak, se sonde vir hom ontbloot kan word (Lev. 4:14a, 23a, 28a; 5:4, 5).

Bekendmaking van die redes vir die uitspraak bied die beswaarde ook 'n behoorlike geleentheid om die uitspraak en die redes daarvoor, in die geval van vermeende regskrenking, vir toetsing aan die meerdere vergadering voor te lê. Die versuim van 'n verhoorvergadering om redes vir sy uitspraak te verstrek, kan in bepaalde gevalle fataal vir die belanghebbende se saak wees as hy sou besluit om te appelleer. Sonder verstrekking van die redes waarop die uitspraak gebaseer is, is dit dikwels prakties onmoontlik vir die belanghebbende om die foutiewe interpretasie van feite, verkeerde beoordeling, ongeoorloofde doel van die uitspraak, of 
male fides aan te toon, omdat hy dit eenvoudig nie kan bewys nie (Wiechers, 1984:240, 241; Corder, 1980:170, 171).

Deur die redes vir die uitspraak behoorlik aan te gee, kan die volle uitspraak weer eens aan die toets van die Woord onderhewig gestel word, indien een van die betrokke partye verontregting sou vermoed.

\section{Die nemo iudex in propria causa-beginsel}

As eerste vereiste van dié beginsel tel dat die verhoorvergadering nie bevooroordeel mag wees nie. 'n Onbevooroordeelde verhoor is 'n duidelike Skrifopdrag: "Moenie partydig wees as julle 'n saak verhoor nie, luister na klein en groot ..." (Deut. 1:17); "Dit is nie goed om partydig te wees vir die skuldige en om die onskuldige sy reg te ontsê nie" (Spr. 18:5).

Die rede vir die opdrag tot 'n onpartydige verhoor word uitdruklik aangegee: "Wie regspreek, is in diens van God" (Deut. 1:17).

In die kerk gaan dit om die regering van Jesus Christus. Wie $\mathrm{Hy}$ tot regspraak roep, doen dit nie op eie gesag nie, maar doen dit in sy Naam. Die oortreding van die reël van absolute onpartydigheid is vir die Here 'n gruwel (Amos 5:7, 15, 24; Jes. 5:20, 21; Matt. 7:1-5; 23:23).

In ontwikkelde regstelsels geld dat niemand (behalwe in die geval van 'n absolute monarg) oor homself, sy eie belange, familie en groep regspreek nie. Elke persoon is deur sy eie situasie, insig en belange eensydig betrokke en kan daarom moeilik onbevooroordeeld oordeel (Spoelstra, 1989:206). In hierdie verband is die woorde van C.J. Hewart, wat in verskeie hofuitsprake in Suid-Afrika aangehaal is, van belang: "It is of fundamental importance that justice should not only be done, but should manifestly and undoubtedly be seen to be done" (Baxter, 1984:557).

Indien iemand byvoorbeeld deur besondere vriendskapsbande, of naby familiebande, aan ' $n$ appellant verbonde is, moet hy homself daarvan weerhou om op die appèlkommissie te dien en/of aan die besluit van die vergadering deel te neem. Persone wat met 'n keurstem die betrokke besluit help neem het, mag eweneens nie op die appélkommissie dien of aan die besluit deelneem nie. So mag ook 'n persoon wat op die mindere vergadering by wyse van advies by die besluitvorming betrokke was, nie 
in 'n besluitvormende hoedanigheid op die appèlkommissie van die meerdere vergadering opgeneem word nie. Niemand mag regter in sy eie saak wees nie. Geregtigheid moet nie alleen in feite en in werklikheid geskied nie, maar ook die uiterlike beeld van geregtigheid moet gehandhaaf word.

\section{Gevolgtrekkings}

* In hierdie bydrae is ' $n$ duidelike verwysingsbasis in die Skrif aangetoon vir die beginsels van die reëls van 'natuurlike geregtigheid', soos hierdie reëls in die algemene reg geformuleer word.

* Die reëls van 'natuurlike geregtigheid' is derhalwe nie 'n oorspronklike vinding van die algemene reg nie. Die fundamentele of universele beginsels van geregtigheid wat ten grondslag daarvan lê, is in die Skrif gegee en plek-plek selfs in gebruike en in voorskrifte as reëls van fundamentele geregtigheid geformuleer.

* Hierdie bydrae beklemtoon nie alleen die onmisbaarheid van die reëls van 'natuurlike geregtigheid' vir die kerklike regspraak nie, maar beklemtoon veral ook die onmiskenbaarheid van die Skrifbegronding van die genoemde reëls vir die kerkregtelike toepassing daarvan.

* Derhialwe moet die toepassing van fundamentele regsbeginsels, soos gepositiveer in die reëls van 'natuurlike geregtigheid', ook vir kerklike regspraak as 'n Skrifopdrag verstaan word.

\section{Slot}

'n Skriftuurlike paradigma vir kerklike regspraak behels uiteraard meer as hierdie bydrae. Hierdie bydrae wil eerder nuwe deure vir verdere ondersoek open as om ' $n$ finale woord te spreek. Ten slotte is die doel van die artikel om die kerk te dien in een van sy fundamentele funksies: die bediening van die reg van die Here. Juis deur die regspraak van die kerk moet die lamp van geregtigheid in hierdie wêreld brandend gehou word. Dit moet op grond van die fundamentele geregtigheidsbeginsels, wat God ook in sy Woord geopenbaar het, gedoen word sodat die lig van 
geregtigheid wat deur God se genade in Jesus Christus deurgebreek het, in die kerk maar ook vanuit die kerk helder mag skyn.

\section{Bibliografie}

BAUR, J. 1965. Gott, Recht und weltliches Regiment im Werke Calvins. Bonn : Bouvier.

BAXTER, L. 1984. Administrative Law. Johannesburg : Juta.

BOHATEC, J. (1937) 1961. Calvins Lehre von Staat und Kirche: mit besonderer Berücksichtigung des Organismusgedankens. Aalen : Scientia. BOUWMAN, H. 1970a. Gereformeerd kerkrecht, dl. 1. Kampen : Kok. BOUWMAN, H. 1970b. Gereformeerd kerkrecht, dl. 2. Kampen : Kok. CALVYN, J. (1559) 1984. Institusie van die Christelike godsdiens, 1. (Vertaal deur Simpson, H.W.) Potchefstroom : C.J.B.

CALVYN, J. 1970. De Handelingen der apostelen, dl. 2. (Vertaal deur Wielenga, G.) 2de dr. Goudriaan : De Groot.

CORBETT, C.J. et al. 1989(4). Administrator Transvaal, et al. versus Traub, et alia. The South African Law Report : 731-764, Dec.

CORDER, H. 1980. The Content of the Audi Alteram Partem Rule in South African Administrative Law. Tydskrif vir Hedendaagse RomeinsHollandse Reg, 43:156-177.

CRAIG, P.P. 1992. Legitimate Expectations: a Conceptual Analysis. The Law Quarterly Review, 108:79-98, Jan.

CRAIGIE, P.C. 1981. The Book of Deuteronomy. 3de dr. Grand Rapids, Mich. : Eerdmans.

DE JONG, J. 1918. Verklaring van de kerkenordening van de Nationale Synode van Dordrecht van 1618-1619: college-voordrachten van prof. dr. F.L. Rutgers over Gereformeerd Kerkrecht, dl. 4. Rotterdam : Libertas.

DU PLOOY, A. le R. 1982. Kerkverband: 'n Gereformeerd-kerkregtelike studie. Potchefstroom : PU vir CHO. (Proefskrif - Th.D.)

FABIUS, D.P.D. 1895. Zonde en recht. Leiden : Donner.

FABIUS, D.P.D. 1890 . Mozaïsch en Romeinsch recht. Amsterdam : Wormser.

GISPEN, W.H. 1954. De Spreuken van Salomo, dl. 2. (Korte Verklaring der Heilige Schrift.) Kampen : Kok.

GROSHEIDE, F.W. 1954. Het evangelie volgens Mattheüs. 2de hers. dr. (Commentaar op het Nieuwe Testament.) Kampen : Kok.

KERKORDE van die Gerefunneerde Kerke in Suid-Afrika. 1980. Potchefstroom : C.J.B. 
HK. 1992. Die Heidelbergse Kategismus of onderwysing in die Christelike leer. 3de Hersiene Uitgawe. (In Die Berymde Psalms en Skrifberyminge. Kaapstad : N.G.Kerk-Uitgewers, p. 517-556.)

KOEHLER, L. \& BAUMGARTNER, W. 1958. Lexicon in Veteris Testamenti Libros. Leiden : Brill.

MURRAY, J. 1979. The Epistle to the Romans. (The New International Commentary on the New Testament.) Grand Rapids, Mich. : Eerdmans.

PIENAAR, G. 1982. Die gemeenregtelike regspersoon in die Suid-Afrikaanse Privaatreg. Potchefstroom : PU vir CHO. (Proefskrif - LLD.)

RIDDERBOS, H. 1967. De Pastorale Brieven. (Commentaar op het Nieuwe Testament.) Kampen : Kok.

ROSE INNES, L.A. 1963. Judicial Review of Administrative Tribunals in South Africa. Johannesburg: Juta.

RUTGERS, F.L. 1894. Het Kerkrecht: in zoover het de kerk met het recht in verband brengt. Amsterdam : Wormser.

SADLER, T.H.N. 1979. Die kerklike tughandeling. Pretoria : N.G. Kerkboekhandel.

SMIT, C.J. 1984. God se orde vir sy kerk. Pretoria : N.G. Kerkboekhandel.

SMIT, C.J. 1985. Kerkreg en kerkorde in die lig van God se reg en orde vir sy kerk. Potchefstroom: PU vir CHO. (Proefskrif - Th.D.)

SPOELSTRA, B. 1986. Die kerklike appèl. (In Smit, C.J., red. In gehoorsaanheid: opgedra aan prof. dr. G.P.L. van der Linde. Promedia : P.T.P. p. 97-114.)

SPOELSTRA, B. 1989. Gereformeerde kerkreg en kerkregering: 'n Handboek by die Kerkorde. V \& R Pretoria : H.T.S.

SPOELSTRA, B. 1992. Op soek na 'n duidelike reformatoriese paradigma vir kerklike gesag. Hervormde Teologiese Studies, 48 (3 \& 4):901-921, Sept.Nov.

STOKER, H.G. 1967. Oorsprong en rigting, dl. 2. Kaapstad : Tafelberg. STOKER, H.G. 1970. Die aard en rol van die reg: 'n wysgerige besinning. Johannesburg : RAU. (RAU, A36.)

TAITZ, J. 1982. The Application of the Audi Alteram Partem Rule in South African Administrative Law. Tydskrif vir Hedendaagse RomeinsHollandse Reg, 45:254-273.

VISSER, J. 1989. Die tug oor ampsdraers. Potchefstroom : PU vir CHO. WIECHERS, M. 1984. Administratiefreg, 2de uitg. Durban, Pretoria : Butterworth. 


\section{Aangehaalde Wette}

Strafproseswet, wet 51 van 1977.

Wet op die Hooggeregshof, wet 59 van 1959.

Wet op Landdroshowe, wet 32 van 1944. 